\title{
Arterial blood flow is the main source of testicular heat in bulls and higher ambient temperatures significantly increase testicular blood flow
}

\author{
C.M.Q. Barros Adwell a, L.F.C. Brito ${ }^{a}$, E. Oba ${ }^{a}$, R.E. Wilde ${ }^{b}$, G. Rizzoto ${ }^{c}$, J.C. Thundathil ${ }^{\text {c }}$, \\ J.P. Kastelic ${ }^{\text {b, * }}$ \\ ${ }^{a}$ Department of Animal Reproduction and Veterinary Radiology, FMVZ, UNESP, Rubiao Jr. s/n, 18618-000, Botucatu, SP, Brazil \\ ${ }^{\mathrm{b}}$ Agriculture and Agri-Food Canada, Lethbridge Research Centre, PO Box 3000, T1J 4B1, Lethbridge AB, Canada \\ ${ }^{\mathrm{c}}$ Faculty of Veterinary Medicine, Department of Production Animal Health, University of Calgary, 3330 Hospital Drive, Calgary, AB, T2N 4N1, Canada
}

\section{A R T I C L E I N F O}

Article history:

Available online 26 April 2018

\section{Keywords:}

Scrotal/testicular thermoregulation

Testis

Increased testicular temperature

Blood flow

Bulls

\begin{abstract}
A B S T R A C T
Two experiments were done in bulls to determine: total testicular blood flow, testis oxygenation and heat, and effects of ambient temperature on testicular temperatures and blood flow. In Experiment 1, arterial blood flow to testes and testicular oxygenation and heat were determined in Angus bulls $(n=8)$. Blood temperature and hemoglobin $\mathrm{O}_{2}$ saturation were both greater $(\mathrm{P}<0.0001)$ in the testicular artery than in the testicular vein $\left(39.2 \pm 0.2\right.$ vs $36.9 \pm 0.4{ }^{\circ} \mathrm{C}$ and $95.3 \pm 0.7$ vs $42.0 \pm 5.8 \%$, respectively; mean \pm SEM). Based on testicular blood flow of $12.4 \pm 1.1 \mathrm{~mL} / \mathrm{min}$ and an arterial-venous temperature differential of $2.3^{\circ} \mathrm{C}$, blood contributed $28.3 \pm 5.1 \mathrm{cal} / \mathrm{min}$ of heat to the testis, whereas heat produced by testicular metabolism was estimated at $5.8 \pm 0.8 \mathrm{cal} / \mathrm{min}$ (based on $\mathrm{O}_{2}$ consumption of $1.2 \pm 0.2 \mathrm{~mL} / \mathrm{min}$ ). In Experiment 2, effects of three ambient temperatures $\left(5,15\right.$ and $\left.35^{\circ} \mathrm{C}\right)$ on testicular blood flow and temperatures were determined in 20 Angus bulls. At 35 versus $5^{\circ} \mathrm{C}$, there was greater testicular blood flow $(8.2 \pm 0.9$ versus $4.9 \pm 0.7 \mathrm{~mL} / \mathrm{min} / 100 \mathrm{~g}$ of testicular tissue, $\mathrm{P}<0.05)$, and higher scrotal subcutaneous and intratesticular temperatures $(\mathrm{P}<0.01)$. In conclusion, arterial blood flow was the main source of testicular heat, testes were close to hypoxia, and increased ambient temperature significantly increased scrotal subcutaneous and intratesticular temperatures, as well as testicular blood flow. These studies gave new insights into scrotal/testicular thermoregulation in bulls; they confirmed that testes are nearly hypoxic, but challenged the long-standing paradigm that testicular blood flow does not increase when testes become warmer.
\end{abstract}

(๑) 2018 Elsevier Inc. All rights reserved.

\section{Introduction}

Testes must be below body temperature for production of morphologically normal, motile sperm in mammals in which testes are located within a scrotum. In bulls, the difference between corebody and testicular temperature is $\sim 4-5^{\circ} \mathrm{C}$ [1]. It is well established that maintenance of optimal temperature is a complex physiological process involving the scrotum, testicular vascular cones and testes [2-6]. Regardless, despite many studies in this area, there are still knowledge gaps regarding scrotal/testicular thermoregulation.

\footnotetext{
* Corresponding author. Department of Production Animal Health, University of Calgary, Faculty of Veterinary Medicine, 3330 Hospital Drive NW, Teaching Research and Wellness (TRW) Building, Room 1E15, Calgary, AB, T2N 4N1, Canada.

E-mail address: jpkastel@ucalgary.ca (J.P. Kastelic).
}

In a theoretical model of testicular thermoregulation in men, the main determinant of testicular temperature was heat supplied by arterial blood, which was a function of blood flow and arterialvenous temperature difference [7]. However, there is limited information on testicular blood flow in bulls and there are apparently no reports comparing contributions of arterial blood and local metabolism as sources of testicular heat.

There is a long-standing paradigm that testes operate on the edge of hypoxia and that whereas increases in testicular temperature causes increase $\mathrm{O}_{2}$ demand, there is a lack of a concomitant increase in testicular blood flow, resulting in hypoxia that is the underlying cause of abnormal spermatogenesis [8]. Furthermore, heat applied directly to the scrotum of rams either did not affect testicular blood flow or resulted in increased flow only when testicular temperature exceeded body temperature (reviewed by 
Setchell [2]). However, in a recent study in rams, we inferred that hyperthermia and not hypoxia was the underlying cause of impaired spermatogenesis following testicular hyperthermia [9]. Exposure of bulls to high ambient temperatures in environmentally controlled chambers decreased semen quality [10,11], but effects of changes in ambient temperature on testicular blood flow in bulls have apparently not been reported.

Mechanisms controlling scrotal/testicular thermoregulation in bulls and responses of bull testes to increased ambient temperatures are very important, as it is well known that increased testicular temperatures reduce proportions of morphologically normal and motile sperm, and their fertility. Objectives were to determine total testicular blood flow, contributions of arterial blood and local metabolism as sources of testicular heat, testis oxygenation, and effects of ambient temperature on testicular blood flow in bulls.

\section{Materials and methods}

\subsection{Experiment 1}

Angus bulls $(\mathrm{n}=14), 18$ mo-old and $\sim 500 \mathrm{~kg}$ were used to evaluate testicular arterial blood flow, testicular $\mathrm{O}_{2}$ consumption, and contributions of arterial blood and metabolism as sources of testicular heat. All bulls were classified as satisfactory breeders after a standard breeding soundness evaluation (mean scrotal circumference and proportion of morphologically normal sperm were $33.6 \mathrm{~cm}$ and $89 \%$, respectively) and mean daytime ambient temperature during the experimental period was $21^{\circ} \mathrm{C}$. Following caudal epidural anesthesia (40 mg xylazine in saline; total volume, $5 \mathrm{~mL}$ ), bulls were restrained in left lateral recumbency on a surgical tilting-table before other measurements were taken. Body (rectal) temperature was determined with a digital thermometer (Barnant 100; Barnant Co., Barrington, IL, USA) and scrotal surface temperatures of the top (SST) and bottom (SSB) aspects of the scrotum were determined with an infrared thermography camera (Model DTIS 500; Emerge Vision, Sebastian, FL, USA). Two black bottles containing warm and cool oil, respectively, with known surface temperatures (determined with a hand-held infrared thermometer; Model IT-330; Horiba, Tokyo, Japan) were held close to the scrotum to serve as temperature references. The infrared thermography camera was positioned $\sim 1 \mathrm{~m}$ behind the scrotum and images were frozen, captured on a flash card, and subsequently downloaded to a computer for image analysis (AGA 3.0 software). Average, top and bottom scrotal surface temperatures were determined as described [1].

Total testicular blood flow was determined using an electromagnetic blood flowmeter (Model RC 1000; Microm Instruments, Los Angeles, CA, USA). An incision was made on the scrotal neck to expose the right testicular vascular cone (TVC). The testicular artery was exposed $(\sim 3 \mathrm{~cm})$ above the TVC and a C-shaped transducer (2 or $3 \mathrm{~mm}$ in diameter) connected to the flowmeter was placed around the artery. Blood samples were anaerobically collected into heparinized syringes from the testicular artery and testicular vein above the TVC for evaluation of hemoglobin $\mathrm{O}_{2}$ saturation. Syringes were capped, placed in ice, immediately transported to the laboratory, and evaluated with a blood gas analyzer (STAT Profile 5; Nova Biomedical, Waltham, MA, USA). Scrotal subcutaneous (SQ) and intratesticular (IT) temperatures were recorded from the top (T), middle (M) and bottom (B) of the scrotum and testis, respectively, using needle thermocouples and a digital thermometer (Barnant 100), as described [1]. Testicular arterial and venous blood temperatures were also recorded above the TVC using needle thermocouples. After all measurements were taken, testes were removed and weighed.
The contribution of testicular arterial blood as a source of testicular heat was determined, considering that each milliliter of arterial blood contributed one calorie for each degree of temperature difference between arterial and venous blood [7]. Testicular $\mathrm{O}_{2}$ consumption was calculated using the equation: $\mathrm{O}_{2}$ consumption $=$ hemoglobin $(\mathrm{g} / \mathrm{dl}) \times 1.36 \mathrm{O}_{2} / \mathrm{g}$ hemoglobin $\mathrm{x}$ difference in saturated hemoglobin between arterial and venous blood $\mathrm{x}$ total testicular blood flow $(\mathrm{mL} / \mathrm{min}) \times 0.01 \mathrm{dL} / \mathrm{mL}$. Heat produced by testicular metabolism was calculated considering that each milliliter of $\mathrm{O}_{2}$ results in production of 4.83 calories; both the capacity of hemoglobin to carry $\mathrm{O}_{2}$ and heat produced by $\mathrm{O}_{2}$ metabolism are standard values [12].

Student's $t$-test was used to determine differences between testicular arterial and venous blood for temperature and $\mathrm{O}_{2}$ saturation. Multivariate analysis of variance with Hotelling's $t$-test was used to determine effects of position (top, middle and bottom) on scrotal subcutaneous and intratesticular temperatures.

\subsection{Experiment 2}

Before Experiment 2 was performed, a preliminary trial was conducted to compare the electromagnetic blood flowmeter used in Experiment 1 with other equipment specifically designed for animal use (Animal Research Flowmeter Model T106/T206; Transonic Systems Inc., Ithaca, NY, USA) that used larger C-shaped transducers ( 2 or $3 \mathrm{~cm}$ in diameter). In the preliminary trial, 10 Angus bulls were prepared as described in Experiment 1, and total testicular blood flow was determined, as described in Experiment 1, using both sets of equipment. Based on this preliminary trial, blood flow evaluated with the equipment specific for animal use was greater than the flow evaluated with the equipment used in Experiment 1 . Therefore, the animal research flowmeter was used for testicular blood flow determination in Experiment 2.

Twenty Angus bulls, 14 mo-old and $\sim 500 \mathrm{~kg}$ were used in Experiment 2 to evaluate effects of ambient temperature on testicular arterial blood flow and scrotal, testicular, and testicular arterial and venous temperatures. All bulls were classified as satisfactory breeders after a standard breeding soundness evaluation (mean scrotal circumference and proportion of morphologically normal sperm were $32.4 \mathrm{~cm}$ and $80 \%$, respectively). Bulls were randomly allocated into three groups for evaluation of effects of ambient temperature $\left(5,15\right.$ and $\left.35^{\circ} \mathrm{C}\right)$.

In a room with controlled ambient temperature, bulls were subjected to anesthesia, restraint, and measurement of body temperature, as described in Experiment 1. Scrotal surface temperatures of the top and bottom were determined at the caudal aspect of the scrotum over the right testis using a hand-held infrared thermometer (Horiba Model IT-330). Total testicular blood flow, and scrotal subcutaneous, intratesticular, and testicular artery and vein temperatures were determined as described in Experiment 1.

One-way ANOVA was used to determine effects of ambient temperature on body, scrotal, testicular, and testicular arterial and venous temperatures, and on total testicular blood flow. Student's $t$-test was used to determine differences between dorsal and ventral scrotal surface temperatures and differences in temperature between testicular arterial and venous blood. Multivariate analysis of variance with Hotelling's $t$-test was used to determine effect of position (top, middle and bottom) on scrotal subcutaneous and intratesticular temperatures. Pearson correlations were calculated between testicular blood flow and all temperature end points (combined for all three ambient temperatures).

\subsection{Animal care and statistical analyses}

Protocols for both experiments were reviewed and approved by 
the Lethbridge Research Centre Animal Care Committee and were conducted in accordance with the standards of the Canadian Council on Animal Care (https://www.ccac.ca/). For each end point, normal distribution and equal variance were verified prior to analysis. All statistical analyses were performed using the Statistical Analysis System (SAS Institute, Cary, NC, USA). For all analyses, $\mathrm{P}<0.05$ was considered significant, whereas $\mathrm{P}>0.05$ but $<0.10$ was considered a tendency.

\section{Results}

\subsection{Experiment 1}

Body and scrotal surface temperatures were $39.6 \pm 0.13$ and $30.9 \pm 0.4{ }^{\circ} \mathrm{C}$, respectively (mean $\pm \mathrm{SEM}$ ). Scrotal subcutaneous temperature at the top of the scrotum tended $(\mathrm{P}<0.1)$ to be higher than the temperature at the bottom of the scrotum $(32.4 \pm 0.5$, $31.8 \pm 0.4$, and $31.4 \pm 0.3^{\circ} \mathrm{C}$ at top, middle and bottom, respectively; top-to-bottom gradient: $\left.-1.0 \pm 0.4{ }^{\circ} \mathrm{C}\right)$. Position did not significantly affect intratesticular temperatures $(34.4 \pm 0.5,34.4 \pm 0.4$, and $34.2 \pm 0.3^{\circ} \mathrm{C}$ at top, middle and bottom; top-to-bottom gradient: $-0.2 \pm 0.1^{\circ} \mathrm{C}$. Blood temperature and hemoglobin $\mathrm{O}_{2}$ saturation were greater $(\mathrm{P}<0.0001)$ in the testicular artery than in the testicular vein $\left(39.2 \pm 0.2\right.$ vs $36.9 \pm 0.4^{\circ} \mathrm{C}$ and $95.3 \pm 0.7$ vs $42.0 \pm 5.8 \%$, respectively). Total testicular blood flow was $12.4 \pm 1.1 \mathrm{~mL} / \mathrm{min}(\sim 4.5 \mathrm{~mL} / \mathrm{min} / 100 \mathrm{~g}$ of testicular tissue $)$. Testicular $\mathrm{O}_{2}$ consumption was $1.2 \pm 0.2 \mathrm{~mL} / \mathrm{min}$. Therefore, testicular metabolism produced $5.8 \pm 0.8 \mathrm{cal} / \mathrm{min}$, whereas arterial blood contributed $28.3 \pm 5.1 \mathrm{cal} / \mathrm{min}$.

\subsection{Experiment 2}

Before starting Experiment 2, a preliminary trial was performed to measure testicular blood flow determined with ultrasonic blood flow equipment specifically designed for animal use; the result was approximately double the blood flow determined with equipment used in Experiment $1(26.5 \pm 1.0$ vs $12.4 \pm 1.1 \mathrm{~mL} / \mathrm{min}$, respectively).

Body, scrotal, testicular, and testicular blood temperatures at

\section{Table 1}

Mean ( ${ }$ SEM) body, scrotal, testicular, and testicular blood temperatures in bulls at three ambient temperatures.

\begin{tabular}{llll}
\hline \multicolumn{4}{c}{ Ambient temperature $\left({ }^{\circ} \mathrm{C}\right)$} \\
\cline { 2 - 4 } & 5 & 15 & 35 \\
\hline Body temperature $\left({ }^{\circ} \mathrm{C}\right)$ & $38.4 \pm 0.2^{\mathrm{a}}$ & $39.1 \pm 0.2^{\mathrm{ab}}$ & $39.3 \pm 0.1^{\mathrm{b}}$ \\
Scrotal surface temperature $\left({ }^{\circ} \mathrm{C}\right)$ & & \\
Top & $28.5 \pm 0.3^{\mathrm{a}, \mathrm{x}}$ & $30.6 \pm 0.4^{\mathrm{b}, \mathrm{x}}$ & $33.5 \pm 0.4^{\mathrm{c}}$ \\
Bottom & $25.2 \pm 0.6^{\mathrm{a}, \mathrm{y}}$ & $27.2 \pm 0.8^{\mathrm{a}, \mathrm{y}}$ & $32.5 \pm 0.4^{\mathrm{b}}$ \\
Gradient & $3.3 \pm 0.6^{\mathrm{a}}$ & $3.4 \pm 0.6^{\mathrm{a}}$ & $1.0 \pm 0.2^{\mathrm{b}}$ \\
Scrotal subcutaneous temperature $\left({ }^{\circ} \mathrm{C}\right)$ & & \\
Top & $29.9 \pm 0.8^{\mathrm{a}, \mathrm{x}}$ & $34.1 \pm 0.5^{\mathrm{b}, \mathrm{x}}$ & $35.2 \pm 0.2^{\mathrm{b}, \mathrm{x}}$ \\
Middle & $28.2 \pm 0.7^{\mathrm{a}, \mathrm{y}}$ & $32.6 \pm 0.5^{\mathrm{b}, \mathrm{xy}}$ & $34.5 \pm 0.2^{\mathrm{b}, \mathrm{y}}$ \\
Bottom & $27.2 \pm 0.7^{\mathrm{a}, \mathrm{y}}$ & $31.8 \pm 0.5^{\mathrm{b}, \mathrm{y}}$ & $34.0 \pm 0.3^{\mathrm{c}, \mathrm{y}}$ \\
Gradient & $2.7 \pm 0.5$ & $2.3 \pm 0.4$ & $1.2 \pm 0.3$ \\
Intratesticular temperature $\left({ }^{\circ} \mathrm{C}\right)$ & $31.7 \pm 0.8^{\mathrm{a}}$ & $34.1 \pm 0.2^{\mathrm{b}, \mathrm{x}}$ & $34.9 \pm 0.3^{\mathrm{b}, \mathrm{x}}$ \\
Top & $31.85 \pm 0.7^{\mathrm{a}}$ & $34.1 \pm 0.2^{\mathrm{b}, \mathrm{x}}$ & $35.2 \pm 0.24^{\mathrm{b}, \mathrm{xy}}$ \\
Middle & $32.9 \pm 0.7^{\mathrm{a}}$ & $34.9 \pm 0.3^{\mathrm{b}, \mathrm{y}}$ & $35.9 \pm 0.2^{\mathrm{b}, \mathrm{y}}$ \\
Bottom & $-1.2 \pm 0.3$ & $-0.9 \pm 0.3$ & $-1.0 \pm 0.23$ \\
Gradient & & \\
Testicular blood temperature* $\left({ }^{\circ} \mathrm{C}\right)$ & $35.8 \pm 1.14^{\mathrm{a}}$ & $37.4 \pm 0.8^{\mathrm{ab}, \mathrm{x}}$ & $39.0 \pm 0.3^{\mathrm{b}, \mathrm{x}}$ \\
Arterial & $33.2 \pm 1.08$ & $34.7 \pm 0.8^{\mathrm{y}}$ & $36.2 \pm 0.5^{\mathrm{y}}$ \\
Venous & $2.6 \pm 0.43$ & $2.7 \pm 0.4$ & $2.8 \pm 0.3$ \\
Gradient & & \\
\hline
\end{tabular}

*Dorsal to the testicular vascular cone.

${ }^{\mathrm{a}-\mathrm{c}}$ Within a row, means without a common superscript differed $(P<0.05)$.

${ }^{\mathrm{x}-\mathrm{z} W i t h i n}$ a column (and end point), means without a common superscript differed $(P<0.05)$ three ambient temperatures are shown (Table 1 ). Body temperature at $5{ }^{\circ} \mathrm{C}$ was lower $(\mathrm{P}<0.05)$ than at 15 or $35^{\circ} \mathrm{C}$, with no difference between the latter two groups. Top and bottom scrotal surface temperatures were greatest at $35^{\circ} \mathrm{C}$ and least at $5{ }^{\circ} \mathrm{C}(\mathrm{P}<0.0001)$, although bottom temperatures were not different at ambient temperatures of 5 vs $15^{\circ} \mathrm{C}(\mathrm{P}>0.05)$. Top scrotal surface temperature was greater $(\mathrm{P}<0.001)$ than bottom temperature at 5 and $15^{\circ} \mathrm{C}$, although there was no difference at $35^{\circ} \mathrm{C}$, due to a smaller top-to-bottom temperature gradient $(\mathrm{P}<0.01)$ at $35^{\circ} \mathrm{C}$. Top and middle scrotal subcutaneous temperature were lowest $(\mathrm{P}<0.001)$ at $5{ }^{\circ} \mathrm{C}$, whereas bottom temperature was lowest at $5{ }^{\circ} \mathrm{C}$ and highest at $35^{\circ} \mathrm{C}(\mathrm{P}<0.0001)$. Top scrotal subcutaneous temperature was greater $(P<0.001)$ than bottom temperature at all ambient temperatures and the top-to-bottom temperature gradient tended $(\mathrm{P}<0.1)$ to be smaller at $35^{\circ} \mathrm{C}$. Top, middle and bottom intratesticular temperatures were lower $(\mathrm{P}<0.001)$ at $5{ }^{\circ} \mathrm{C}$. Bottom intratesticular temperature was greater $(\mathrm{P}<0.05)$ than top temperature at 15 and $35^{\circ} \mathrm{C}$, although there was no difference at $5^{\circ} \mathrm{C}$. Testicular arterial blood temperature was lower at 5 vs $35^{\circ} \mathrm{C}$, although $15^{\circ} \mathrm{C}$ was not different from either. Venous blood temperature tended $(\mathrm{P}<0.1)$ to increase with increased ambient temperature. Testicular arterial blood was warmer $(\mathrm{P}<0.001)$ than venous blood at 15 and $35^{\circ} \mathrm{C}$, with no difference at $5^{\circ} \mathrm{C}$.

Ambient temperature affected testicular blood flow/100 g of testes, with the least flow at $5{ }^{\circ} \mathrm{C}(4.9 \mathrm{~mL} / \mathrm{min})$, which was lower $(\mathrm{P}<0.05)$ than flow at $35^{\circ} \mathrm{C}(8.2 \mathrm{~mL} / \mathrm{min})$. Furthermore, testicular blood flow had significant positive correlations with several end points (Table 2), including SST $(r=0.30)$ and SSB $(r=0.27)$, scrotal subcutaneous temperatures $(\mathrm{r} \sim 0.44)$ and top and bottom intratesticular temperatures $(r \sim 0.25)$, although there was no significant correlation between testicular blood flow and rectal temperature. Interestingly, rectal temperatures was significantly correlated with several scrotal and testicular temperature end points (Table 3).

\section{Discussion}

Total testicular blood flow in Experiment 1 was approximately half the flow in Experiment 2, because the sensors used in Experiment 1 had smaller diameters and probably caused some arterial constriction, resulting in reduced blood flow. Using equipment specific for animal use with larger diameter sensors, total testicular blood flow in bulls was $\sim 25-28 \mathrm{~mL} / \mathrm{min}$ or $\sim 7 \mathrm{~mL} / \mathrm{min} / 100 \mathrm{~g}$ of testicular tissue. Testicular blood flow in the second study seemed higher than that previously reported in bulls (Setchell [2], $5 \mathrm{~mL}$ / $\mathrm{min} / 100 \mathrm{~g}$ of testicular tissue), but was comparable to values in rams [8,13-15]. Furthermore, men, rodents, and dogs, which have much smaller testes than bulls and rams, had greater blood flow per unit of testicular mass, with values ranging from $\sim 14$ to $25 \mathrm{~mL} /$ $\min / 100 \mathrm{~g}$ of testicular tissue [16-19].

To the best of our knowledge, testicular oxygenation in bulls has not been reported. Hemoglobin $\mathrm{O}_{2}$ saturation was close to $100 \%$ in the testicular arterial blood, but only $40 \%$ in the venous blood. Similarly, in previous experiments in rams, $\mathrm{O}_{2}$ saturation in the testicular vein was $\sim 50 \%$ of that in the testicular artery and was less than in most other organs ( $65 \%$ ), indicating the high $\mathrm{O}_{2}$ demand for testicular metabolism and consistent with the hypothesis that testes operate on the brink of hypoxia $[8,13]$. Based on blood flow, blood temperatures and testicular $\mathrm{O}_{2}$ uptake, it was evident that arterial blood was the main source of testicular heat, contributing approximately five times more heat than that produced locally by testicular metabolism, in agreement with a testicular thermoregulation model for men [7]. Furthermore, that estimated testicular arterial blood flow was approximately half in Experiment 1 versus Experiment 2, the absolute contribution of arterial blood as a source of testicular heat is undoubtedly even greater. 
Table 2

Pearson correlations between testicular blood flow/100 g of testes and various temperature end points.

\begin{tabular}{lll}
\hline End point $\left({ }^{\circ} \mathrm{C}\right)$ & $\mathrm{r}$ & $\mathrm{P}$ value \\
\hline SST & 0.30 & $\mathrm{P}<0.01$ \\
SSB & 0.27 & $\mathrm{P}<0.05$ \\
SS gradient & 0.11 & $\mathrm{NS}$ \\
SQT & 0.43 & $\mathrm{P}<0.001$ \\
SQM & 0.47 & $\mathrm{P}<0.001$ \\
SQB & 0.41 & $\mathrm{P}<0.01$ \\
SQ gradient & 0.03 & $\mathrm{NS}$ \\
ITT & 0.24 & $\mathrm{P}<0.05$ \\
ITM & 0.25 & $\mathrm{NS}$ \\
ITB & 0.26 & $\mathrm{P}<0.05$ \\
IT gradient & 0.001 & $\mathrm{NS}$ \\
Rectal temperature & 0.16 & $\mathrm{NS}$ \\
\hline
\end{tabular}

$\mathrm{SS}=$ scrotal surface; $\mathrm{SQ}=$ scrotal subcutaneous; $\mathrm{IT}=$ intratesticular.

$\mathrm{T}=$ top; $\mathrm{M}=$ middle; $\mathrm{B}=$ bottom

Testicular arterial blood flow significantly increased with increasing ambient temperature in the present study. Similarly, in our own recent studies in rams (unpublished), testicular blood flow increased as testes were warmed. It was noteworthy the findings from the current bull study and our previous ram study were not consistent with the classical paradigm that testicular blood flow fails to increase in response to increasing testicular temperature, thereby creating testicular hypoxia [8]. In another study in rams, blood flow to the testis increased $26 \%$ when testicular temperature was increased to $36^{\circ} \mathrm{C}$ by applying heat directly to a testis [15]. However, in that study, the testis was outside the scrotum, and the authors commented that, due to the absence of the scrotum, their findings did not refute the classic assertion that blood flow remains constant when testes are warmed. Clearly, there are now multiple indications that testicular blood flow increases in response to increased testicular temperature, indicating that the long-standing paradigm of no change in testicular blood flow in association with increased testicular temperature is likely incorrect.

Scrotal surface and subcutaneous top-to-bottom temperature gradients were positive, but decreased with increased ambient temperature, similar to previous reports [4,5]. Intratesticular temperature also increased with increased ambient temperature, but unlike other reports $[1,4,5,20]$, there was a significant difference between top and bottom intratesticular temperatures in Experiment 2. That there were significant positive correlations between testicular blood flow and several of the scrotal and testicular temperature end points supported data from Experiment 1, indicating blood flow was the major source of heat to the testes. In addition, the absence of a significant correlation between blood flow and

Table 3

Pearson correlations between rectal temperature and various temperature end points.

\begin{tabular}{lll}
\hline End point $\left({ }^{\circ} \mathrm{C}\right)$ & $\mathrm{r}$ & $\mathrm{P}$ value \\
\hline SST & 0.38 & $\mathrm{P}<0.01$ \\
SSB & 0.29 & $\mathrm{P}<0.05$ \\
SS gradient & 0.08 & $\mathrm{NS}$ \\
SQT & 0.38 & $\mathrm{P}<0.01$ \\
SQM & 0.40 & $\mathrm{P}<0.01$ \\
SQB & 0.29 & $\mathrm{P}<0.05$ \\
SQ gradient & 0.01 & $\mathrm{NS}$ \\
ITT & 0.25 & $\mathrm{P}<0.05$ \\
ITM & 0.13 & $\mathrm{NS}$ \\
ITB & 0.38 & $\mathrm{P}<0.01$ \\
IT gradient & 0.003 & $\mathrm{NS}$ \\
\hline
\end{tabular}

$\mathrm{SS}=$ scrotal surface; $\mathrm{SQ}=$ scrotal subcutaneous; $\mathrm{IT}=$ intratesticular.

$\mathrm{T}=$ top; $\mathrm{M}=$ middle; $\mathrm{B}=$ bottom rectal temperature, as described by Skinner and Louw [11], emphasized the autonomy of testicular thermoregulation.

Variations in blood flow in response to increased testicular temperature may also be affected by genetics. For example, testicular blood flow did not change with increased scrotal temperature in rams selected for skin wrinkling, but increased in rams selected against skin wrinkling [14]. Furthermore, in bulls, spermatogenesis was less severely affected in Bos indicus than in Bos taurus bulls when exposed to high ambient temperatures [10,11]. Various morphological differences may contribute to the greater resistance of Bos indicus bulls to high ambient temperatures bulls by conferring a better testicular blood supply and facilitating heat transfer between the testicular artery and veins [6], although differences in testicular blood flow may also be involved.

In conclusion, in bulls, we determined that: 1 ) the testes operate close to hypoxia, 2) arterial blood was the main source of testicular heat, and 3) testicular blood flow increased in response to increasing ambient temperature. Therefore, this study clarified testicular oxygenation and heat sources. However, the longstanding paradigm that testicular blood flow does not increase in response to increased testicular temperature, and that the ensuing hypoxia affects spermatogenesis, was not supported, as there were significant increases in testicular blood flow following increased testicular temperatures. Therefore, these studies have filled important knowledge gaps regarding scrotal/testicular thermoregulation in bulls.

\section{Conflicts of interest}

The authors declare no conflicts of interest.

\section{Acknowledgments}

This research was supported by internal funds from the Agriculture and Agri-Food Canada Lethbridge Resarch Centre. We thank the barn staff at the Lethbridge Research Centre for animal husbandry and technical assistance.

\section{References}

[1] Kastelic JP, Coulter GH, Cook RB. Scrotal surface, subcutaneous, intratesticular; and intraepididymal temperatures in bulls. Theriogenology 1995;44:147-52.

[2] Setchell BP. The scrotum and thermoregulation. In: Setchell BP, editor. The mammalian testis. Ithaca: Cornell University Press; 1978. p. 90-103.

[3] Waites GMH. Thermoregulation of the scrotum and testis: studies in animals and significance for man. In: Zorgniotti W, editor. Temperature and environmental effects on the testis. New York: Academic Press; 1991. p. 9-17.

[4] Kastelic JP, Cook RB, Coulter GH. Contribution of the scrotum and testes to scrotal and testicular thermoregulation in bulls and rams. J Reprod Fertil 1996; 108:81-5.

[5] Kastelic JP, Cook RB, Coulter GH. Contribution of the scrotum, testes, and testicular artery to scrotal/testicular thermoregulation in bulls at two ambient temperatures. Anim Reprod Sci 1997;45:255-61.

[6] Brito LF, Silva AE, Barbosa RT, Kastelic JP. Testicular thermoregulation in Bos indicus, crossbred and Bos taurus bulls: relationship with scrotal, testicular vascular cone and testicular morphology, and effects on semen quality and sperm production. Theriogenology 2004;61:511-28.

[7] Sealfon AI, Zorgniotti AW. A theoretical model for testis thermoregulation. Adv Exper Med Biol 1991;286:123-35.

[8] Waites GM, Setchell BP. Effect of local heating on blood flow and metabolism in the testis of the conscious ram. J Reprod Fertil 1964;8:339-49.

[9] Kastelic JP, Wilde RE, Rizzoto G, Thundathil JC. Hyperthermia and not hypoxia may reduce sperm motility and morphology following testicular hyperthermia. Vet Med 2017;62:437-42.

[10] Johnston JE, Naelapaa H, Frye JB. Physiological responses of Holstein, Brown Swiss and Red Sindhi crossbred bulls exposed to high temperatures and humidities. J Anim Sci 1963;22:432-6.

[11] Skinner JD, Louw GN. Heat stress and spermatogenesis in Bos indicus and Bos taurus cattle. J Appl Physiol 1966;21:1784-90.

[12] Ruch TC, Patton HD. In: Physiology and biophysics. nineteenth ed. Philadelphia: W.B. Saunders Co;; 1965.

[13] Setchell BP, Waites GMH. Blood flow and the uptake of glucose and oxygen in 
the testis and epididymis of the ram. J Physiol 1964;171:411-25.

[14] Fowler D, Setchell B. Selecting Merino rams for ability to withstand infertility caused by heat. 2. The effect of heat on scrotal and testicular blood flow. Austral J Exper Agric 1971;11:143-7.

[15] Mieusset R, Sowerbutts SF, Zupp JL, Setchell BP. Increased flow of testicular blood plasma during local heating of the testes of rams. J Reprod Fertil 1992;94:345-52.

[16] Neutze JM, Wyler F, Rudolph AM. Use of radioactive microspheres to assess distribution of cardiac output in rabbits. Am J Physiol 1968;215:486-95.

[17] Jaffe RA, Free MJ. A miniature friction flow meter for use in the rat testicular artery and other small vessels. J Appl Physiol 1972;32:571-5.

[18] Pettersson S, Söderholm B, Persson JE, Eriksson S, Fritjofsson Á. Testicula blood flow in man measured with venous occlusion plethysmography and xenon. Scand J Urol Nephrol 1973;7:115-9.

[19] Glode LM, Robinson J, Horwitz LD. Scrotal hypothermia and testicular blood flow in the dog. Absence of thermal regulation. J Androl 1984;5:227-9.

[20] Kastelic JP, Cook RB, Coulter GH, Wallins GL, Entz T. Environmental factors affecting measurement of bovine scrotal surface temperature with infrared thermography. Anim Reprod Sci 1996;41:153-9. 